\title{
Nordic Dickens: Dickensian Resonances in the Work of Bjørnstjerne Bjørnson
}

\author{
Kathy Rees, Wolfson College, University of Cambridge
}

On 19 March 1870, the Illustrated London News reported on the last of Charles Dickens's farewell readings at St. James's Hall ('Mr. Chas Dickens's Farewell Reading' 301). Three weeks later, Norsk Folkeblad featured this same article, translated into Norwegian ('Charles Dickens's Sidste Oplaesning' 1). At that time, the editor of Norsk Folkeblad was the 38-year-old journalist, novelist, and playwright Bjørnstjerne Bjørnson. He recognised the importance of this event and, unlike his English counterpart, he made it front-page news. Bjørnson reproduced both the iconic image of the famous writer at his reading desk and the words of Dickens's brief curtain speech wherein he bade farewell to his adoring public. Dickens's novels and journals had long been widely read in Norway, first in German and French translations, later in Danish or Swedish. Sketches by Boz (1836) was popular because of its representation of English customs, especially among the lower classes: one of its tales, 'Mr Minns and his Cousin', was included on the English syllabus of Norwegian schools from as early as 1854 (Rem 413). American Notes (1842) was also much discussed on account of the rising numbers of Norwegian emigrants crossing the Atlantic. ${ }^{1}$ Written Danish and Norwegian were virtually the same language in the

How to cite this book chapter:

Rees, K. 2020. Nordic Dickens: Dickensian Resonances in the Work of Bjørnstjerne Bjørnson. In: Bell, E. (ed.), Dickens After Dickens, pp. 35-55. York: White Rose University Press. DOI: https://doi.org/10.22599/DickensAfterDickens.c. Licence, apart from specified exceptions: CC BY-NC 4.0 
19th century, so in 1849-50 Norwegian readers could follow the serialisation of David Copperfield in the Copenhagen daily paper Faedrelandet at almost the same time as the original monthly numbers were being published in London (Ewbank 299). By the early 1870s, Dickens's complete works had been translated into Danish by Ludwig Moltke, making his oeuvre widely accessible to Norwegian readers (Schlicke 568). When Dickens died, only two months after Bjørnson's newspaper article, the Norwegian people mourned him deeply; no other non-Scandinavian author, before or since, has received such heartfelt tributes.

\section{Bjørnson's response to Dickens}

The so-called 'big four' in 19th-century Norwegian literary history, Bjørnson (1832-1910), Henrik Ibsen (1828-1906), Jonas Lie (1833-1908), and Alexander L. Kielland (1849-1906) were all influenced by Dickens's work to varying degrees (Rem 414-16), but Bjørnson is notable within this group as the one who responded with sustained critique rather than homage. By the date of the newspaper article, Bjørnson was established as a well-known writer, but, more controversially, as a radical agitator in the cause of Norwegian independence. Norway had had a complicated political history since the passing of her last native-born king in 1387. Thereafter, she had been caught in a mesh of Scandinavian politics which brought her into union with Denmark or Sweden or, at times, with both countries. From 1536, Norway was subject to Danish rule, only in 1814 to be ceded by Denmark to the king of Sweden. In the first decades after 1814, Norway was backward economically and intellectually and more isolated than ever before, or later. As a result, the rate of emigration to America grew steadily, reaching an unprecedented peak between 1866 and 1873, when 110,896 Norwegians tried their fortunes in the New World (Larsen 467). In order to focus Norwegian attention onto its own history and society, Bjørnson gave his people a whole literature, including the national anthem 'Ja vi elsker dette landet' ('Yes, We Love This Country'), folk tales of peasant life, dramas based on Norway's medieval history, and the new genre of social dramas of contemporary life introduced by him in the 1870s, exposing corruption in politics and journalism (The Editor 1874) and in business (The Bankrupt 1875), as well as challenging the double standard in marriage (A Gauntlet 1883). ${ }^{2}$ He believed that, for Norway to develop, the contribution of educated and self-reliant women was essential, hence his fictional depiction of females who develop strength and courage by overcoming challenges of many kinds. Bjørnson strove for the emancipation of the motherland and for her female population; ${ }^{3}$ it was his feminist outlook that set Bjørnson on a collision course with Dickens, who was well known for his limiting portrayal of women. 
The popularity of Dickens's novels in Norway worked subtly against Bjørnson's political and social aims in two ways. First, Britain was an imperialist power that, like Sweden, colonised weaker nations; by the ready availability of Dickens's writing, Norwegian readers became engrossed in English customs and manners and were distracted from Bjørnson's focus on native culture. Second, Dickens's promotion of the traditional domestic ideal undermined Bjørnson's efforts to galvanise Norwegian women into independent thought and action. As demonstrated by Michael Slater in Dickens and Women (1983) and by Patricia Ingham in Dickens, Women and Language (1992), Dickens created a spectrum of female stereotypes that incorporated dysfunctional mothers, from the comically garrulous Mrs Nickleby to the sinister Mrs Clennam, asexual pre-pubescent girls from the dollish Dora Spenlow to the saintly Agnes Wickfield, angelic 'orphans' from Little Nell to Esther Summerson, fallen women from the penitent Nancy to the stainless Little Em'ly, and public campaigners like the strident Mrs Pardiggle and the obsessed Mrs Jellyby. ${ }^{4}$ Dickens's stereotypes quickly hardened into 'species' of women, instantly definable by a name. The name Mrs Jellyby, for example, became synonymous in modern journalism with any working woman believed to be neglecting her family. She appears, invariably in a negative light, in such articles as 'Are Clever Women Good Housewives?' (Illustrated Household Journal 1880) and 'Should Married Women Engage in Public Work?' (Woman at Home 1891). As George Henry Lewes commented in 1872:

Universal experiences became individualised in these types; an image and a name were given, and the image was so suggestive that it seemed to express all that it was found to recall, and Dickens was held to have depicted what his readers supplied. Against such power criticism was almost idle. ('Dickens in Relation to Criticism' 145)

Against such power, however, Bjørnson strove to challenge assumptions that trapped 19th-century women into attitudes of submission and positions of inequality.

\section{Bjørnson and Dickens's common experiences}

Despite the cultural differences and the 20 years that separated their births, Bjørnson and Dickens shared many similar experiences in their family lives and careers. Both knew physical and emotional hardship in childhood, and thereafter interrogated parent-child relationships in their fiction. ${ }^{5}$ Both gained an insight into government through working as political journalists early in their careers: from 1832 to 1834 , Dickens was employed by The Mirror of Parliament to cover debates in the House of Commons, and from 1854 to 1856 
Bjørnson worked as a correspondent for Christiania-Posten, reporting on the Lagting (Upper House) of the Norwegian parliament. Both began their publishing careers in their mid-twenties by concentrating on the lives of ordinary people: writing as 'Boz', Dickens's short pieces (published 1833-36) described the unseen lives of the London poor, while Bjørnson's rustic tales (launched in 1857) brought the unnoticed lives of the peasants to the foreground. Both worked as journal or newspaper editors: Dickens founded and edited Household Words (1850-59) and All the Year Round (1859-70), while Bjørnson edited Norsk Folkeblad and Illustreret Folkeblad, and co-edited Aftenbladet, though for much shorter periods; this role provided both men an opportunity to comment on national affairs. Both were passionate about theatre: Dickens involved himself in amateur theatricals, acting, producing, and directing, and displaying his knowledge of the stage in works like Nicholas Nickleby, while Bjørnson was a prolific playwright and directed several of his own stage plays. Both used fiction as a tool for social reform, highlighting abuses in political, religious, and educational institutions, while at the same time aiming to challenge the conscience of the individual reader. Both men distanced themselves from church dogma, but retained a belief in God as a force for good. It is possible that Bjørnson felt frustrated that the writing of a man with whom he shared so many commonalties should so impede his own political objectives and literary ambitions.

The differing priorities on the issue of education for women emerge markedly in the context of the American tours undertaken by both men: Dickens visited twice in 1842 and 1867-68, Bjørnson in 1880-81. Both were attracted by the democratic constitution and egalitarian principles of the New World government, and both men were impressed with the state institutions they visited in Massachusetts: it is in their respective comments about schools and factories that their contrasting attitudes to the status of women start to emerge. When, in American Notes, Dickens applauds the access that the female workers at the well-run mills at Lowell have to a piano, to a circulating library, and to their own periodical (78), he seems not to see the need for such aspiring women to be given educational opportunities. Bjørnson, on the other hand, writes a passionate letter to Dagbladet on 30 December 1880, describing Wellesley College, where 'all the professors are women' and where female students are taught chemistry, physics, botany, geology, astronomy, and music and pay only 'about two hundred and fifty dollars a year for instruction, room, board, and all that goes with it' (Haugen 110). Wellesley College was founded in 1870, the year of Dickens's death, so it is not possible to make a direct comparison with Dickens's female schoolrooms. However, in my discussion of the school for girls in Bjørnson's novel, Flags Are Flying in Town and Harbour (1884), modelled on Wellesley College, I suggest that Bjørnson is demonstrating how progressive Norwegian education could be, given appropriate political and economic investment, and showing that it is a far cry from the institutions of the Misses Crumpton in Boz to that of Miss Twinkleton in The Mystery of Edwin Drood (1870). 


\section{Bjørnson and the depiction of the frightened child}

It should come as no surprise, then, that Bjørnson's first appropriation of a Dickensian device is extracted from a school scene: Paul Dombey's arrival at Dr Blimber's Academy. In his novel The Fisher Maiden (1868), Bjørnson invokes Dombey and Son (1848) to highlight the static nature of English patriarchy in comparison with Norway's openness to feminist social mobility. Bjørnson focuses on the moment when Paul's misery is expressed through the repetition of Dr Blimber's words in the pulsating beats of the clock:

'And how do you do, Sir?' [Dr Blimber] said to Mr Dombey; 'and how is my little friend?'

Grave as an organ was the Doctor's speech; and when he ceased, the great clock in the hall seemed (to Paul at least) to take him up, and to go on saying, 'how, is, my, lit, tle, friend?' over and over and over again. (142)

Bjørnson employs this device to convey the anxieties of a similarly aged girl called Petra, who is the eponymous 'fisher maiden'. She is the impetuous and naïve daughter of a tough woman called Fish-Gunlaug who runs an inn for seamen. Without intending to deceive anyone, Petra becomes engaged to three different men, and, when this state of affairs becomes known, brawling breaks out across the town. The mob surrounds her mother's inn, smashing its windows and singing a lampoon against Petra. Gunlaug arranges for Pedro, the local recluse (a sad, timid man towards whom she had once felt great affection but who had lacked the courage to marry her) to help Petra escape by boat to Bergen. While waiting to leave, Petra feels sick with anxiety and becomes aware of 'an old-fashioned clock ... ticking out the seconds' (130). ${ }^{6}$ Bjørnson's use of the word 'old-fashioned' here is very resonant, it being the adjective that Dickens repeatedly applies to Paul Dombey. Suddenly, by way of explanation for her choice of the strange Pedro to help them, the mother says 'I used to know that man once' (130). The sentence:

kept whistling in [Petra's] ears. The clock took it up, and began to tick out, 'I - used - to - know - that - man - once'. Whenever, in her subsequent life, Petra encountered close, faint air, that room straightway stood before her with the memories of her sickness and the clock's 'I - used - to - know - that - man - once'. Whenever she went on a steamer ... [the smells] always made her feel sea-sick at once, and constantly through her sickness that room stood day and night before her eyes, and in her ears was the sound of the clock ticking out its 'I - used - to - know - that - man - once.' (131)

The sentence encapsulates past, present, and future. Gunlaug is thinking about the past, about Pedro's failure to live up to her expectations of him. Petra, aware 
of the ticking clock, thinks of the present, and her sick feelings at the tumult that her thoughtlessness has precipitated. The narrative looks to the future, and how Petra's seasickness would henceforth always trigger the memory of this moment. By setting this scene on the steamer, Bjørnson seems also to invoke the imagery of the river and the sea which runs through Dombey and Son, suggesting the mutability of life and the relentlessness of time passing. Paul is preoccupied by fancies of flowing water, and 'felt forced, sometimes, to try to stop it - to stem it with his childish hands - or choke its way with sand' (216-17). Paul is attempting to arrest the passage of time, to hold onto the present; he tries to defeat the past which associated his birth with his mother's death, casting her 'out upon the dark and unknown sea that rolls all round the world' (12) and to resist the future, for he senses that the sea is bearing me away, I think!' (217). Through marine imagery and its temporal symbolism, both writers convey the turbulent minds of children who cannot orient themselves in a confusing world.

The different genders of the protagonists reflect the priorities of their authors. In Dombey, mid-Victorian English society is founded on masculinity, money, and the railway, all things hard, cold, and correct, while The Fisher Maiden embraces passion, love, and literature, many things muddled and mistaken but sincere. Despite their different cultures, Petra and Paul are similar in their resistance to adulthood. When Blimber asks, 'Shall we make a man of him?' Paul replies, 'I had rather be a child' (142-3) and, likewise, when Petra is obliged to move into her own attic room on Confirmation Day 'it seemed to her that to be grown up was the most wretched thing to happen' (55). Whereas Little Paul succumbs to the weight of paternal expectation and dies, Petra is set loose to find her own way, and to grow into her vocation as an actress. The book ends with Petra's still stern but now proud mother in the audience of the theatre where Petra will soon perform. Mother and daughter have - without marrying - achieved independence, fulfilment, and success on their own terms.

\section{The deaf-mute character in the works of Dickens and Bjørnson}

The struggle for a working-class woman to gain a living was challenging in 19th-century Britain and Norway, but particularly when their efforts were exacerbated by disability. The fact that both Dickens and Bjørnson employ a deaf-mute character in their work is noteworthy because it is such an unusual theme for a writer of this period. As Jennifer Esmail points out, 'a deaf character's relationship to language ... disqualifies him or her from conventional representation in Victorian fiction' (992). Although the depiction of communication between a deaf-mute character and a hearing person poses authorial challenges both on page and on stage, Dickens and Bjørnson both achieve it, though with very different emphases and outcomes. Dickens's 1865 Christmas story 'Dr Marigold' relates the childhood and early adulthood of a deaf-mute 
character named Sophy, ${ }^{7}$ and Bjørnson's political play The King (1877) features the 15-year-old deaf-mute servant Anna. Dickens's mode is to have Marigold, an itinerant hawker or 'Cheap Jack', describe his interactions with Sophy, which are achieved through an ad hoc form of signing which after several years renders her receptive to formal instruction at the London Deaf and Dumb Asylum. Similarly, Bjørnson's stage directions are explicit about manual signing: Anna 'talks to Gran [her master] on her fingers and receives orders from him in the same manner' (206). What is remarkable is not simply that both young women sign manually but that both writers emphasise this mode at a time when oralism, the anti-signing movement that forced deaf people to lip-read and speak, prevailed. ${ }^{8}$ Esmail notes that Dickens was 'reportedly' a governor of the London Asylum (998), and the emphasis on signing in 'Dr Marigold' suggests his opposition to oralism, a stance which Bjørnson also adopts.

Dickens's deaf-mute character has triggered variant readings among critics. In the story, the infant Sophy is rendered 'unkempt and uncommunicative' by her abusive stepfather, until rescued by the eponymous Marigold, who names her after his own dead child. At 16, Sophy enters the Asylum, and emerges after two years 'such a woman, so pretty, so intelligent, so expressive' (10). At the school, Sophy falls in love with a deaf youth whom she subsequently marries and accompanies to China, where he works as a clerk (the representation of marriage between two deaf characters is also unusual in Victorian fiction). The climax of the story pivots on whether or not their child will be deaf, and the reader shares Marigold's suspense as five years pass without news from China. Then, Sophy's family returns to England, and on Christmas Day the child greets Marigold with 'a pretty voice', exclaiming 'Grandfather!' (47). Not only is the child not deaf but she is bilingual, conversing both by speech and by signing. In Fictions of Affliction: Physical Disability in Victorian Culture (2004), Martha Stoddard Holmes argues that Dickens's plot is ultimately conservative in its ableist emphasis on the priority of speech and hearing. By celebrating the child's escape from deafness, argues Holmes, the story represents 'a good example of narrative fiction palliating the concerns about hereditary 'defect' raised by Victorian medical science' (88). Holmes's argument is strengthened by the final image of Marigold weeping 'happy and yet pitying tears' ('Doctor Marigold's Prescriptions' 47, my emphasis); Dickens's use of 'pity' here is problematic since it conveys such condescending assumptions about disability. Carolyn Ferguson reads the word 'pity' in terms of Marigold's own recovery from past grief at the loss of his biological child, the first 'Sophy' (20), but this serves only to highlight the ambiguity of the ending. Certainly the notion of 'pity' treats deafness as a condition of loss, lack, suffering, and sorrow, an attitude that undermines Dickens's apparent support for the practice of marriage and parenthood by deaf people.

Bjørnson seems to share Dickens's interest in deafness but utilises his deafmute character, Anna, quite differently. ${ }^{9}$ In The King, Anna is thrust into the maelstrom of Norwegian politics, ${ }^{10}$ and comes to represent the colonised subject, 
denied both a voice and a future. As the devoted servant of Harald Gran, the Minister of the Interior, Anna finds herself at the heart of the conflict between monarchists and republicans in Norway. Gran is an old friend of the king but also committed to a republican future for Norway and his dual allegiance finally results in his being killed for 'treason' by a former republican friend. Although the king sympathises with the republicans, and wishes to abolish the monarchy and live as a private citizen, he is prevented from doing so by the vested interests of the military, the church, and business, for whom the king 'is the padlock on [the] cashbox' (224). During the course of the play, the king is gradually deprived of all those who are close to him, until he is left in the cynical company of the General, the Priest, and the Mayor. Into that gathering comes Anna, sorrowing bitterly at the death of her master, Gran. The obsequious insincerities of the three representatives of the ruling powers contrast with Anna's candour. Bjørnson's stage directions have Anna entering the room: she 'throws herself at the King's feet, embracing his knees in despairing sorrow', and the king says 'Ah, here comes a breath of truth!' (279). Resolving to commit suicide, the king wants only Anna with him: 'You are the very picture of dumb loyalty. ... I do not deserve to have such as you to watch by my side' (280). When a loud pistol shot is heard, 'noise and confusion grows louder every minute' but Anna stumbles onto the stage, 'her hands stretched out before her, as if she did not know where she was going' (291), not only symbolising muteness but also suggesting the blindness that threatened to dominate Norway's political future. In contrast to Dickens's tendency towards normativisation, bringing Sophy out of the margins and having her join society as a contented wife and the mother of a hearing child, Bjørnson's Anna is set on a downward trajectory, rendered doubly mute once she is deprived of her master, Gran, with whom she could communicate by signing, and directionless without his protection. She is Bjørnson's symbol of the Norwegian soul in the 1880s, deprived of voice and vision by the colonising powers.

\section{The danger of laughter in The Pickwick Papers (1836)}

On two occasions, Bjørnson makes an overt reference to a novel by Dickens as if signalling to his reader its intertextual relationship with his own narrative. Magnhild (1877) is a case in point: ${ }^{11}$ in an isolated village, hidden amid 'high bold mountains' (9), the family of the Lutheran parish priest settles down to a reading of The Pickwick Papers. The Dickensian title subtly imports its own linguistic, figurative, and structural conventions into Bjørnson's fictional world, and the outcome represents an incongruous mix of discourses. Malcolm Andrews comments that Pickwick had 'acted as a mighty transfusion of humour into English literary culture, with its anaemic devotion to sensibility and its growing Evangelical puritanism' (7), and Bjørnson replicates that dynamic by transfusing the farcical and playful world of Pickwick into the stiff and sombre 
sphere of Norwegian Lutheranism. Magnhild at the time of this reading is an eight-year-old orphan, her 14 relatives having recently perished in a landslide. The local priest took Magnhild to live with his family 'for the present, in order to set a good example', but Magnhild cannot regard this as a permanent home because, as the priest's wife reminds her, 'she was a poor girl who had neither relatives nor future of her own' $(18,45) .{ }^{12}$ Into this somewhat begrudging atmosphere, Pickwick brings unwonted merriment. Bjørnson is, however, inviting the reader to consider the role of humour, for, although Wesley Brown reads this scene as a reflection of 'the mirth caused in Bjørnson's own home by similar readings of Pickwick Papers' (72), ${ }^{13}$ it is actually that very 'mirth' that triggers the tragedy that consumes the novel's eponymous heroine.

Bjørnson seems to be intent on outdoing Dickens in his creation of the character who interrupts the evening reading. This unexpected visitor is Skarlie, the saddler: 'The kitchen door slowly opened and a large bald head, with a snub nose and smiling countenance, was thrust in' (25). Dickens frequently applies equivalents of the noun phrase 'smiling countenance' to Pickwick, varying from 'beaming countenance, 'amiable countenance, 'very pleased countenance', and 'benevolent countenance' $(848,113,115,476$, and 203). Bjørnson seems to underline the physical connection between Pickwick and Skarlie by employing the phrase twice in relation to the latter. This cannot be dismissed simply as a translator's preference, for in the Norwegian text Skarlie is first described as having a 'smilende miner' and, eight lines later, a 'smilende ansigt' (Samlede Digter-Verker, 4:146). Skarlie's body is then revealed, inch by inch: 'A short leg in very wide trousers was next introduced, and this was followed by a crooked and consequently still shorter one' (25). At this point, Bjørnson seems also to invoke the comic 'flying waiter' of Drood, whose leg was 'always preceding himself and tray (with something of an angling air about it), by some seconds' (96), but Bjørnson challenges our inclination to laugh as the extent of Skarlie's disability is revealed:

The whole figure stooped as it turned on the crooked leg to shut the door. The intruder thus presented to the party the back of the beforementioned large head, with its narrow rim of hair, a pair of square-built shoulders, and an extraordinarily large seat, only half-covered by a pea-jacket. Again he turned in a slanting posture toward the assembled party, and once more presented his smiling countenance with its snub nose. (25)

The mechanical nature of 'its' turning movement and 'its narrow rim of hair' transforms Skarlie into an automaton, imitating Dickens's trait of sometimes representing human movement in terms of 'simple mechanism, always in one way, (instead of moving with the infinite fluctuations of organisms, incalculable yet intelligible)' (Lewes 146). ${ }^{14}$ Bjørnson echoes Dickens's notion of the permeability of the boundary between the human and the machine. 
A significant source of the comic lies in the recognition of one's own superiority over what appears incongruous or subhuman. On Skarlie's arrival, Magnhild and the priest's two daughters 'bowed low over their work [and] a suppressed titter arose first from one piece of sewing and then from another' (25). The girls' reaction recalls that of Little Nell in The Old Curiosity Shop (1841), who felt 'much inclined to laugh at [Quilp's] uncouth appearance and grotesque attitude' (51). The parallel between Skarlie and Quilp is further reinforced by the fact that each one 'thrusts' his head into view, forcibly imposing himself on the company (Magnhild 25; OCS 253). Skarlie's oddness is further emphasised when he takes over the reading of Pickwick, using 'such an unfamiliar pronunciation of the names of the personages and localities introduced that the humour of the text became irresistible' (26). Skarlie's identification with the Dickensian world is reiterated by his ventriloquising of it. His rendering of Pickwick instigates 'laughter which no one now attempted to restrain', and when the girls went to bed they imitated the saddler's mode of walking and talking: 'Magnhild was the most adroit in mimicking; she had observed him the most closely' (26-7). ${ }^{15}$ Magnhild, so diminished in the priest's household, at last feels superior to another person.

In Magnhild, Bjørnson draws attention to the act of laughter by over-using the word, particularly in connection with Skarlie. 'Laughter', in its noun and verb forms, appears in Pickwick Papers 147 times, that is, more than in any other novel by Dickens; it is emitted in 'fits' and in 'peals' or 'bursting out', sometimes in 'a roar' $(423,476,776,342)$. Skarlie's contact with the girls involves a 'frequent intermingling of jests' and 'they gradually ceased laughing at him and laughed instead at the witty things he said' (27). In Skarlie's absence, the word disappears from the pages, until a year later when he returns, and the three girls carry in his luggage 'notwithstanding his laughing resistance, [and] their laughter accompanied him as he stood in the passage taking off his furs' (33, emphasis mine). Their group laughter is now an affirming activity. As suggested above, laughter can be a complex reaction that is often related to perceptions of power. Initially, the girls' laughter had marked Skarlie as Other, but he has gradually deflected this in order to become one of the group, laughing at the external Other. The target for Skarlie's ridicule is now Magnhild's adoptive family: 'Magnhild had never viewed her surroundings with critical eyes; she would now laugh heartily with Skarlie over the priest's last sermon ... it was all described so comically' (34). Magnhild does not realise that Skarlie is slowly detaching her from her last precarious anchor: the somewhat neglectful surrogate family. By Skarlie's laughter, the innocent Magnhild is beguiled. The origin of Magnhild's plight was Pickwick Papers: it had predisposed her to laughter, and Skarlie exploited that chink of openness until she was ensnared. Believing herself to be an encumbrance on the priest and, having no alternative, Magnhild tearfully agrees to marry the elderly saddler.

Bjørnson problematises the marriage between Magnhild and Skarlie. It cannot be viewed as a union of good and evil, of innocent and perverted, such 
as that projected by Quilp's lusting after Little Nell, by Arthur Gride's designs on Madeline Bray, or by Uriah Heep's pursuit of Agnes Whitfield. Bjørnson's Skarlie is not one-dimensional like Dickens's grotesques: he is not demonic like Quilp (indeed, Skarlie became disfigured by rescuing a child from a burning house), not miserly like Gride (Skarlie showers gifts on Magnhild), nor obsequious like Heep (Skarlie is a successful and confident trader). Despite this, Magnhild is physically repelled by the old man: 'she could not stir, could not grasp a single thought except that she was in the clutches of a great lobster' (48). Over the course of several years, they become estranged: Magnhild develops a hopeless love for a consumptive composer, while Skarlie engages in an affair with a drunken and degraded local woman. Finally, Magnhild leaves Skarlie and plans a visit to America 'in order to see and to learn', hoping to 'return [someday] and teach others' (211). Bjørnson here identifies with his protagonist, for he too, as he wrote to Rasmus B. Anderson, would go to America 'in order to learn' (Haugen 141). Magnhild's future is vague: she will venture west, a woman separated from her husband, resolving to learn a skill by which she can ultimately contribute to Norwegian society. Despite Magnhild's new-found independence, the ending is dark. The combination of laughter and Lutheran duty has generated only misery; in the wrong environment, Bjørnson seems to suggest, Pickwickian humour may be destructive.

\section{Bjørnson and the tearing up of David Copperfield (1850)}

Bjørnson's critique of Dickens's representation of women becomes more pronounced in Flags Are Flying in Town and Harbour (1884), a work more commonly known in Britain as The Heritage of the Kurts, following its publication in English in 1892. This novel marks the second occasion when Bjørnson had imported a Dickensian text, that of David Copperfield, into his Norwegian fiction. In 1900, when the journal Norske Intelligenssedler sought to advertise a Norwegian edition of David Copperfield, its editor elicited comments about the book from leading writers and public figures. When Bjørnson was approached, he was 'not unusually, in a rush', says Tore Rem, and so he referred the journal's readers to Heritage, indicating that he had written about Copperfield there (414). Rem explains: 'In that novel a young mother struggles to read foreign books, but is completely taken in by her birthday present, Copperfield, which was then England's favourite novel' (414). In order to convey the idea that Bjørnson depicts David Copperfield as a fascinating read, Rem misrepresents the scene with the young mother. A closer look at this novel and the context of this scene shows that Bjørnson's intention was rather different from Rem's interpretation. In his critique of Copperfield, Bjørnson strikes at the heart of Dickens's oeuvre, not only because of its autobiographical aspects but also because Dickens had declared this work to be 'a favourite child' (Preface to the 1867 edition, xvii). 
In Heritage, Bjørnson challenges Dickens with the scientific and philosophical thinking that became current after Copperfield. H.H. Boyesen notes that, between 1867 and 1872, Bjørnson experienced 'a period of barrenness, as far as external productivity went, but in reality [it was] a period of intellectual absorption and incubation' during which he read Herbert Spencer, Charles Darwin, J.S. Mill, Max Müller, and Hippolyte Taine (1), and he draws upon some of these ideas in Heritage. The novel traces the growth from birth to manhood of Tomas Rendalen, who is the last of five generations of the Kurt family. Over a period of 200 years, each Kurt son has inherited his father's vicious predisposition to violence, infidelity, drunkenness, and insanity, and the local town is peopled with the illegitimate offspring of this notorious lineage. The story pauses in the mid19th century, when Tomas's father, having just beaten his mother, suddenly dies of apoplexy, some months before Tomas is born. His mother, Tomasina, is so desperate to terminate the Kurt dynasty that on first discovering her pregnancy she considers suicide, but instead resolves to extinguish the bloodline by educating her son in the ways of moral and social conduct. Tomas is a difficult baby, and causes his mother much distress. Having exhausted her supply of child-rearing manuals, Tomasina escapes into David Copperfield, and her copy of that book becomes the object of the 'last great struggle' between mother and son (69). The day is Tomas's second birthday (not Tomasina's birthday, as Rem avers) and he resents his mother's absorption in Dickens's novel. Far from 'struggling to read foreign books', as Rem claims, Tomasina, the daughter of a headmaster, had spent time before her marriage working in England, France, and Germany, acquiring fluency in all three languages and becoming an 'unusually clever teacher' (38). Indeed, she is so imaginative and receptive a reader that 'all the life-like forms gathered themselves round little Tomas ... and she dreamt of little Em'ly and little Tomas' (67). For Tomasina, this fictional world segues seamlessly into her own. Tomas, frustrated by his mother's preoccupation, takes his revenge when she is absent from the room by tearing up the volume: 'After the first one or two [pages], he took them out several at a time, twenty in all before his mother returned' (68). By this act, Bjørnson seems to say that he too will do violence to David Copperfield, and that he will disturb the unreflective absorption of readers in Dickens's romanticised story and draw their attention to more demanding questions.

After this dramatic scene, it becomes clear that Copperfield is a pervasive presence in Heritage, and that parallels exist between the characters and issues of both books. The figure of Tomasina resonates with David's surrogate mother, Betsey Trotwood: both marry abusive husbands, and these two eccentric, bespectacled women devote their lives to mitigating the consequences of such humiliation. Just as Aunt Betsey dilutes the male genealogy by renaming David as 'Trot', so Tomasina gives her son the surname 'Rendalen' in order to banish the patronym of Kurt. Tomasina is entrusted with far greater responsibility and professional opportunity than her English counterpart. As part of her mission to 'obliterat[e] the evil example with a good one', she transforms the Kurt 
estate, which for generations had harboured men of violence and insanity, into a school for girls where 'the whole course of education [had] morality as its aim' $(92,70)$. Like David Copperfield, Tomas was born after his father's death, and saddled with an equally burdensome biological inheritance. In both cases, the drama lies in the protagonists' emotional development, the struggle between nature and nurture. David seems destined to repeat the negative behaviour pattern of his parents: his mother, Clara, is irrepressibly girlish, playing on her own immaturity, and David's childlike adoration of Clara later translates into his infatuation with Dora Spenlow, who is as inept and frivolous as Clara had been. David duplicates his father's gullibility in marrying 'a wax-doll', fulfilling Betsey Trotwood's prediction that 'he would be as like his father as it's possible to be, if he was not so like his mother too' (203). David is, however, saved from the consequences of his inherited flaws. Dora dies young, leaving David free to marry Agnes Wickfield, and with her help to become a successful novelist: 'What I am, you have made me, Agnes' (848). He writes the final words of his autobiography with Agnes seated beside him. Dickens's propensity to end his novels with happy marriages is described by Catherine Belsey in Critical Practice (1980) as the final 'reinstatement of order', suggesting that 'a harmonious and coherent world' will always restore itself (240).

No such happy ending is available to Tomas, who must forever 'struggle to free himself from the Kurt inheritance', and, as evident in his impetuous destruction of his mother's book, Tomas is bequeathed an 'unruly nature' and an 'uneven temper' $(186,202)$. As an adult, Tomas travels and studies, and, having read Prosper Lucas's Traité Philosophique de L'Hérédité Naturelle (1847) and Herbert Spencer's Education: Intellectual, Moral, and Physical (1861), he develops a Lamarckian philosophy. He believes that an individual can either degenerate into inherited patterns of immoral or self-destructive behaviour, like the illegitimate offspring of the 'many mad Kurts' who lived in the town, or like Tomas himself can try to fashion his own character by force of will and education. Having presented these theories, Bjørnson then leaves Tomas's fate hanging in the balance. Five years later, when Bjørnson's was writing In God's Way (1889), he brought Tomas Rendalen into that text as a minor character. Tomas confesses to a friend: 'I am not at liberty to love anyone. ... There is madness in our family ... you know how ungovernable I am ... my father was exactly the same' (111). It is as though, during the passing of five years of real time between the novels, Bjørnson imagines Tomas having lost his way and descended into depression and frenzy. Bjørnson is reminding his readers that there are no fairy-tale solutions to the problem of biological inheritance. Tomas's act of tearing up Copperfield as an infant and his chaotic despair in In God's Way evince his rage at being forced to relinquish an optimistic Dickens-style future, to be denied a life as a 'family man' like David. Just as in The King Anna's hopelessness showed up by contrast Dickens's contrived normalisation of disability in 'Dr Marigold', so, through Tomas, Bjørnson challenges Dickens's side-stepping of the complex issues related to 
genetic inheritance in his desire to restore 'a harmonious and coherent world' (Belsey 240).

Bjørnson believes that women should be equipped to make more informed decisions about marriage, and that fiction should not seduce readers into notions of fairy-tale romance. Education was for Bjørnson fundamental to female development, and the school run by Tomasina and her adult son is clearly based on Wellesley College in Boston; it trains its pupils in natural science, theology, gymnastics, and debating, as well as 'history and general literature as branches of knowledge which have an influence in the formation of character' but, most importantly, using Herbert Spencer's axiom, it teaches 'the knowledge how to regulate one's own life' (113). Women, Bjørnson argues in Heritage, need to understand the nature and the power of their own sexuality. In a lecture to the parents, Tomas explains that most adolescent girls undergo:

a period of change [when they] deteriorate and lose their openness, and much of, or all, their industry and sense of order ... therefore our work must be ... completely prepared to meet this physical change. ... For it is no use denying that this exists, or shutting one's eyes to it. (111)

Bjørnson is challenging the sort of education that Dora Spenlow receives. She can only envisage love as something innocent and childlike; Jenni Calder thinks that Dora 'is afraid of sex just as she is afraid of adult responsibility' (101). That Victorian men in general both expected women to be dollish, and then blamed them for being so, is suggested by some of the comments about Dora in the reviews during Copperfield's serialisation. In July 1850, the reviewer of Bell's Life in London asserted that David 'deserves contempt for loving such a thread-paper piece of affectation' (3). The application of so domestic an analogy as a 'thread-paper' (this was a strip of thin soft paper folded into creases so as to form separate divisions for different skeins of thread, and so, when used attributively, means someone feeble and flimsy) is unkindly pertinent given Dora's sad incompetence in housekeeping. One month later, in the Weekly Dispatch, the reviewer observes that:

there is something touching in the childish simplicity of poor Dora; but how many Doras are there in the world who, for lack of a gentle firmness on the part of a husband, convert unconsciously the happiness of the home into a desolation such as now menaces the home of our hero. (502)

Judging by such reviews, Dickens does little in Copperfield to enlighten Victorian men about the double-bind for women who, having been trained to be decorative 'dolls', were suddenly expected on marriage to transform themselves into efficient housekeepers. 
In Heritage, Bjørnson foregrounds the issue of dollishness by featuring actual dolls in the text. When four of the Senior Girls come unexpectedly upon a doll's house, their behaviour is transformed. They are enraptured by its miniaturised domesticity, the 'complete and marvellously dainty kitchen' and 'the sweetest little beds' (159). Then a shift takes place when the dolls are removed from their household trappings: they now become figurines to be glamorised and bedecked for a dolls' court ball. Utterly absorbed, 'eight eyes and forty fingers rummaged' among brocade, silk, and velvet, and 'endless chatter filled the air with fancies' (166). These dolls were not 'baby dolls' but miniature adult dolls, of the type owned by wealthy Victorian women, who would purchase clothing for them from such workers as Jenny Wren, the dolls' dressmaker in Our Mutual Friend (1865). When Jenny Wren describes her work with Charlie Hexham and Bradley Headstone, her references to the 'Fine Ladies' and the dolls become interchangeable: she says, 'I had a doll married, last week, and was obliged to work all night', to which Headstone replies, 'I am sorry your fine ladies are so inconsiderate' (223). Similarly, Bjørnson's Senior Girls identify with the dolls: they turn away from 'playing house' to replicate the socially directed appearance of debutantes at a formal ball, the place where the female adorns herself in order to become 'a lady', an object of desire. This interaction with the dolls represents the girls' shift from domestic to sexual engrossment, and illustrates Tomas's prediction of the adolescent female's 'physical change'.

The girls' daydreams, projected onto the dolls, are safe so long as they are protected from male intrusion. Suddenly, the girls' fantasies are disturbed by an announcement that Consul Engel has unexpectedly arrived, and 'amid smothered cries' the dolls are hastily packed away (170). When he enters the room, the girls are embarrassed because:

the lower part of a doll became visible! It lay there, 'naked and face downwards' as the song says. ${ }^{16}$ Tora tried to cover it up, but the Consul had caught sight of it, and with a 'Pardon me, Froken' he stooped and picked it up ... asking 'What in the world is this?' (170)

When he queried why they had tried to hide 'such a harmless thing' they answered, 'Because the doll was undressed, of course' (171). His banter, directed mainly at the beautiful Tora, causes her to become increasingly identified with the half-naked doll, feeling vulnerable, 'as though she had no dress on at all' (171). A notorious womaniser, Consul Engel represents the intrusion of predatory masculinity into the room, charging the atmosphere with disturbing male sexuality, consuming Tora with 'a feeling of helplessness' so that she departs in tears (172).

Again, there is an echo here of Our Mutual Friend, in terms of the relationship between the doll and exploitative sex. While Headstone struggles to understand Jenny's riddles, Eugene Wrayburn is acutely attuned to Jenny's 
conceit of mixing the fine ladies and the dolls, hinting to her his plan to make the socially inferior Lizzie Hexham his mistress, when he says, 'I'm thinking of setting up a doll, Miss Jenny' (237). As Pam Morris points out, this phrase has only one meaning, that of 'prostitutes dressed in the trashy finery of cheap consumer taste, like one of Jenny Wren's "flaunting dolls"' (137). However, Wrayburn soon realises that he desires Lizzie not as a mistress but as a wife, and it is Lizzie who evades him, being aware of the class gulf between them. Dickens, however, effects a social fairy tale, and Our Mutual Friend ends with their happy marriage.

Like Lizzie Hexham, poverty renders the Norwegian Tora vulnerable to male predators. Unlike the other three Senior Girls who had dressed the dolls, Tora comes from a poor family. She is the eldest of 10 children, the daughter of the chief customhouse officer, 'who drank' (149). Having lived abroad with her shipbroker uncle for some years, she is now middle class by education and aspiration. Following her uncle's death, Tora has had to return home, but gladly escapes 'the hurry-skurry and disorder' of family life by attending Tomas's school (216). During the school holidays, however, she is alone, with no friends in whom she can confide her confused feelings, recently aroused by the attentions of Lieutenant Niels Fürst, a naval officer. Fürst is a man whose 'eyes both laughed and stabbed' (214). We already know from Magnhild that laughter in Bjørnson's work may be ominous, and here its coupling with the penetrative effect of stabbing makes Fürst dangerous. Tora's mother, like many Dickensian mothers, is too preoccupied with her own concerns to provide adequate protection for her daughter, and Tora 'never once thought of' Mrs Holm as a source of refuge (227). Although Tora's training at the school has warned her against being 'an easy prey for a rogue', her sense of sexuality is overwhelming, and 'the danger had something attractive in it' (230). Daily, Tora goes for long walks in the woods, invariably passing Fürst's house; she eludes his early attempts to find her, but increasingly 'the image of the sly, excited, accursed face ... seemed to stab her - to thrill through her' (230). Finally, when Fürst finds her alone in the wood, she cannot control her emotions:

She looked down below her ... she wanted to get up and go away; but her eyes continued fixed on the branches below, there was something dark beneath them. A head pushed its way through, a man - he! ... He looked up. With all her power she raised herself, though her feet felt as heavy as lead; but she did not turn from him, or attempt to go away, and by degrees she lost the desire to do so. Now there was only the stone between them, a wave of terror swept over her and roused her; she turned her head now, staggered a few steps - and met him. She leaned forward, he took her hand, his arm slipped under hers - she felt as though a burning band were round her. She fell so unexpectedly and so heavily that he nearly fell with her. (232) 
Tora finally gives up the struggle between her recognition of Fürst's predatory nature and her susceptibility to his erotic power over her. Needless to say, Bjørnson does not end Heritage with a happy Lizzie/Eugene-style wedding.

Bjørnson prepared us for a female 'fall' many chapters earlier, when Tomasina was so engrossed in Dickens's novel that she 'dreamt of little Em'ly and little Tomas' (67). Dickens excuses Little Em'ly's 'fall' by her dream of becoming 'a lady' and her belief in Steerforth's promises: the sexual act is not described, she is saved before she slips into prostitution, and her transgression is erased by her emigration to Australia. Bjørnson by contrast accounts for Tora's act as a combination of the excitement of being desired and the novelty of sexual emotions, that 'period of change' predicted by Tomas. While Little Em'ly's life 'can be summed up as a string of past participles: seduced, rescued, redeemed, removed' (Ingham 55), Tora actively confronts her seducer and faces the future with her illegitimate baby.

Despite the many correspondences between the lives and career experiences of Dickens and Bjørnson, the most productive aspect of their literary relationship is forged by Bjørnson's frustration with Dickens's circumscription of female competency, and his low expectations of woman's potential contribution beyond the domestic sphere. For Bjørnson, Dickens's women are - like all Norwegian citizens - colonised by a subjugating power. The solution to this colonised state of mind was education, not only in terms of an improved and modernised curriculum, such as he witnessed in America, but also in the acquisition of knowledge about 'regulating one's own life' and developing 'self-awareness leading to self-respect' (Heritage 113). By giving his heroines the same dilemmas as those besetting Dickens's women - poverty, isolation, and disability - but equipping them with the means and the resolve to overcome such problems, Bjørnson hoped that readers of both genders would share his vision of, and responsibility for, the building of a progressive and prosperous Norway. Whereas Dickens's women are generally denied both agency and knowledge, their counterparts in Bjørnson's writings learn, develop, and change during the course of their trials. Rather than resolving women's stories with marriage (Sophy), with death (Dora), or with emigration (Little Em'ly), as is Dickens's custom, Bjørnson sets his women challenges to overcome: young Petra must identify and fulfil her vocation as an actress; Anna must find a way out of civic disorder; Magnhild must go to America to learn; Tomasina must educate her son out of Kurt violence; and Tora must nurture her illegitimate child. In this regard, Bjørnson seems to anticipate some of the neo-Victorian rewritings of Dickensian women, as discussed in relation to Miss Havisham and Rosa Bud in Chapters 4 and 5 of this volume. Invariably independence is foisted upon Bjørnson's women but they are empowered by experience or education to face their demanding tasks and uncertain futures. Bjørnson's engagement with 
Dickens's novels would have energised those Norwegian readers who recognised the intertextual resonances, not only because Bjørnson was advocating the superiority of Norwegian feminist ideology over the attitudes and conventions of the British, who at that time ruled the largest empire in history, but also because he was wrestling with Charles Dickens, the writer who in his lifetime was a global spokesman for his age.

\section{Endnotes}

${ }^{1}$ In addition to the Norwegian fascination with American life in general, Erling Sandmo notes that Dickens's reports from Cherry Hill Prison and his views on the 'Philadelphia system' were included in debates about prison management in Norway in January 1843 (Rem 411-12).

${ }^{2}$ For summaries of these plays, see the Literary Encyclopaedia:

The Editor: https://www.litencyc.com/php/sworks. php?rec=true\&UID=35811. The Bankrupt: https://www.litencyc.com/php/ sworks.php?rec=true\&UID=35814. A Gauntlet: https://www.litencyc.com/ php/sworks.php?rec $=$ true\&UID $=35916$.

${ }^{3}$ The final stanza of Bjørnson's National Anthem illustrates Norway as the motherland:

And, as warrior sires have made her

Wealth and fame increase

At the call we too will aid her

Armed to guard her peace.

${ }^{4}$ Within Dickens's stereotyping there are, of course, many calibrations and complexities. Mrs Nickleby (Nicholas Nickleby), who fails to protect her daughter from such predators as Sir Mulberry Hawk, and the unyielding and vindictive Mrs Clennam (Little Dorrit), who alienates her son by her religiosity, are dysfunctional mothers in very different ways. Dora Spenlow, David Copperfield's first wife, seems to be frightened of sex, while Agnes Wickfield, his second wife, seems too saintly to be associated with the act. Little Nell (The Old Curiosity Shop) and Esther Summerson (Bleak House) are treated as 'orphans' but in fact Nell's grandfather is still alive, as is Esther's natural mother, Lady Dedlock. Nancy is described in the 1841 preface to Oliver Twist as a 'prostitute', but it is generally thought that Dickens was invoking the term to mean a woman living out of wedlock, and, although Little Em'ly (David Copperfield) elopes with Steerforth, her 'fall' is treated sympathetically (see discussion below). In Bleak House, Mrs Pardiggle harangues the lower classes and her own children with religion, while the philanthropist, Mrs Jellyby, is so obsessed with her African projects that she neglects her home and family.

${ }^{5}$ The tensions between young Bjørnson and his father, a stern Lutheran minister who dominated both the family and the parish, finds echoes in 
the strained father-son relationships depicted in Bjørnson's peasant tales, Synnøve Solbakken (1857) and Arne (1858).

${ }^{6}$ As Rob Jacklosky comments in his analysis of The Goldfinch in Chapter 6 of this volume, Donna Tarrt identifies the ticking clock as a peculiarly Dickensian motif, one which transports the protagonist, Theo Decker, from the 21st century into the world of 1850 .

7 This story is the frame for 'Doctor Marigold's Prescriptions', the title of the entire 1865 Christmas number of All the Year Round. In this format, the first part of Dr Marigold's story (3-10) stops when Sophy returns from the Asylum and reads the stories, some of which were written by contributors, characterised as 'prescriptions' with such titles as 'Not to be Taken at Bed-time' or 'To be Taken in Water'. The narrative of 'Dr Marigold' is resumed at the end, under the title 'To be Taken for Life' (45-7), after which Sophy, who has read 'the whole of the foregoing several times over', goes to China with her husband for five years and returns with her child to share Christmas Day with Dr Marigold.

${ }^{8}$ Oralism dominated educational policy in Europe and USA from around the 1860 s to the 1960s. In 1880, the International Congress on the Education of the Deaf enshrined the 'incontestable superiority of speech over signs in restoring the deaf-mute to society' (Scouten 203).

${ }^{9}$ It is very feasible that Bjørnson would have read 'Dr Marigold'; Tore Rem notes that, between 1859 and 1880, 180 articles from All the Year Round were published in the Norwegian press, while the journals themselves were also subscribed to by Norwegian readers and institutions (412).

10 The Swedish king, Oscar II, who ruled Norway from 1872 until his dethronement in 1905, was very offended by The King and personally disliked Bjørnson: on hearing that Bjørnson was leaving for America, Oscar wrote to his prime minister saying ' $I$ agree that there is no great advantage in B.B.'s journey to the New World, especially compared with what it would be if he went to the Other World' (Haugen 142).

11 Magnhild is one of five of Bjørnson's works to be entitled after the female protagonist, the others being Synnøve Solbakken (1857), Halte-Hunda (1858), Maria Stuart I Skotland (1863), and Leonarda (1879). Dickens's only novel so entitled is Little Dorrit (1857), which combines the diminutive adjective that he often applies to his heroines (Little Nell, Little Em'ly) and the patrilineal surname.

12 Like Dickens's orphans, especially Oliver Twist, Magnhild is denied any sense of physical or emotional security in her adoptive home. This theme is further developed by Katie Bell in relation to William Faulkner's character, Joe Christmas, in Light in August (1932): see Chapter 3 of this volume.

13 Brown's assertion is based on an unpublished letter written by Bjørnson's niece, Signe, recalling her childhood visits to Bjørnson's home in Aulestad and mentioning the excitement experienced by the family whenever Dickens was read aloud in the evenings. Discussed on 'Barndomsminner 
fra Aulestad', broadcast on Norsk Rikskringkasting by Guri Stormoen on 1 January 1966 (Brown 71-2).

${ }^{14}$ Just as Skarlie is portrayed as a hybrid human-machine through the use of 'it', so Pete Orford, in Chapter 5, points out Dickens's use of the possessive pronoun to suggest Rosa Bud's androgyny.

15 The observation by Rosemarie Garland-Thomson that, in order to feel a sense of normalcy in their own bodies, mainstream figures are often drawn to look closely at grotesques, is also discussed in Chapter 3 of this volume.

16 The National Library in Oslo, where there is an archive of Norwegian folk songs and ballads, was unable to identify either the phrase 'naken med baken opp' ('naked and face downwards') or the song to which it allegedly belongs. Either the song has been lost or Bjørnson is highlighting the erotic nature of the phrase by implying its source in a popular song.

\section{Acknowledgements}

I wish to record my gratitude to Emily Bell and Claire Wood for their insightful suggestions on this chapter, and to the helpful staff at the Oslo National Library who investigated their Archive of Folk-Songs on my behalf.

\section{Works cited}

Andrews, Malcolm. Dickensian Laughter: Essays on Dickens and Humour. Oxford UP, 2013.

'Are Clever Women Good Housewives?' Illustrated Household Journal and Englishwoman's Domestic Magazine, 1 Nov. 1880, p. 265.

Belsey, Catherine. Critical Practice. Methuen, 1980.

Bjørnson, Bjørnstjerne. The Fisher Maiden. P.F. Collier, 1906.

- Three Dramas: The Editor, The Bankrupt, The King. Translated by Robert F. Sharp. Dent, 1914.

-. Magnhild and Dust. Trans. Rasmus B. Anderson. Doubleday, 1882.

- The Heritage of the Kurts. Translated by Cecil Fairfax. Heinemann, 1892.

—. In God's Way. Translated by E. Carmichael. Heinemann, 1890.

- Samlede Digter-Verker. Gyldendalske Boghandel, 1927.

Boyesen, Hjalmar H. 'Bjørnstjerne Bjørnson.' New York Independent, 7 Oct. 1886, p. 1.

Brown, James Wesley. 'Charles Dickens and Norwegian Belles-Lettres in the Nineteenth Century' Edda: Scandinavian Journal of Literary Research, vol. 2, 1970: pp. 65-84.

Calder, Jenni. Women and Marriage in Victorian Fiction. Thames and Hudson, 1976. 
'Charles Dickens's Sidste Oplaesning.' Norsk Folkeblad, 9 Apr. 1870, p. 1.

Dickens, Charles. Pickwick Papers. Penguin, 1972.

-. The Old Curiosity Shop. Penguin, 2000.

- Dombey and Son. Dent, 1997.

—. David Copperfield. Penguin, 2004.

—. 'Dr Marigold.' Charles Dickens's New Christmas Story: Dr Marigold's

Prescriptions. Harper, 1866: pp. 3-10 and 45-47.

- Our Mutual Friend. Penguin, 1997.

- The Mystery of Edwin Drood. Wordsworth, 1998.

Esmail, Jennifer. “I Listened With My Eyes”: Writing Speech and Reading Deafness in the Fiction of Charles Dickens and Wilkie Collins.' English Literary History, vol. 78, no. 4, 2011: pp. 991-1020.

Ewbank, Inga-Stina. 'Dickens, Ibsen and Cross Currents.' Anglo-Scandinavian Cross-Currents. Edited by Inga-Stina Ewbank, Olav Lausund, and Bjørn Tysdahl. Norvik, 1999: pp. 297-315.

Ferguson, Christine. 'Sensational Dependence: Prosthesis and Affect in Dickens and Braddon.' Literature Interpretation Theory, vol. 19, no. 1, 2008: pp. 1-25.

Haugen, Eva and Einar, editors. Land of the Free: Bjørnstjerne Bjørnson's America Letters 1880-1881. Norwegian-American Historical Association, 1978.

Holmes, Martha Stoddard. Fictions of Affliction: Physical Disability in Victorian Culture. Michigan UP, 2007.

Ingham, Patricia. Dickens, Women and Language. Harvester Wheatsheaf, 1992.

Larsen, Karen. History of Norway. Princeton UP, 2015.

Lewes, George Henry. 'Dickens in Relation to Criticism.' Fortnightly Review, vol. 11, no. 62, 1872, pp. 141-54.

'Literature and Art.' Weekly Dispatch, 11 Aug. 1850, p. 502.

Literary Encyclopaedia. 'Bjørnstjerne Bjørnson' and articles on works: https://www .litencyc.com/php/sheadwords.php?newsearch=yes\&phrase=Bjornson \&searchBtn. Accessed 16 Dec. 2019.

Morris, Pam. Dickens's Class Consciousness: A Marginal View. Macmillan, 1991.

'Mr. Chas Dickens's Farewell Reading.' Illustrated London News, 19 Mar. 1870, p. 301.

Rem, Tore. 'Dickens in Norway'. The Reception of Charles Dickens in Europe, vol. 2, edited by Michael Hollington. Bloomsbury, 2014, pp. 409-29.

Schlicke, Paul. Oxford Reader's Companion to Dickens. Oxford UP, 2000.

Scouten, Edward L. Turning Points in the Education of Deaf People. Interstate Publishers, 1984.

'Should Married Women Engage in Public Work?' The Woman at Home, June 1891, p. 110.

Slater, Michael. Dickens and Women. Dent, 1983.

'The Magazines, Serials etc.' Bell's Life in London, 7 July 1850, p. 3. 